\title{
IFTEKHARRUDIN, F., BOYDEN, J., LONGO, J., AND M. ROHRBERGER, EDS. 2003. POSTMODERN APPROACHES TO THE SHORT STORY. WESTPORT, CONNECTICUT AND LONDON: PRAEGER. 156 PP.
}

\author{
José Francisco Fernández Sánchez \\ University of Almería
}

\begin{abstract}
Short story theory is nowadays a lively area of critical discussion, but this is a new phenomenon. Until very recently if a monograph on the short story was published, it constituted an isolated orphan among a countless list of titles delving into other narrative forms. "No more than a decade ago," wrote Susan Lohafer and Jo Ellyn Clarey in 1989 "referring to a 'field' of short story criticism would have seemed odd" (1989: vii). The book by Lohafer and Clarey, Short Story Theory at a Crossroads set the standard for successive studies that increased in number in the nineties and in the first years of the new millennium. Instead of being exhaustive books, written by a single author with the aim of settling the matter (the works by Walter Allen (1981) or John Bayley (1988) are excellent examples of its kind), the new trend collected the opinions of several experts in one same volume with the basic aim of promoting discussion on the short story.

The book by the pioneering scholar in the academic field of the short story Charles E. May, The New Short Story Theories (1994), follows this pattern. It contains classic pieces by authors like Poe or Brander Matthews, together with contemporary texts by writers like Julio Cortázar or Nadine Gordimer. It deals with aspects of definition of the short story, together with historical considerations and
\end{abstract}


issues of particular practitioners of the form. It offers an open and dynamic presentation of the multiple aspects which characterize the short story.

The recent impulse in short story studies is also indebted to the work done by the Society for the Study of the Short Story, an organization created in the early nineties in order to encourage the analysis of this literary genre. Two of the editors of the volume under discussion, Postmodern Approaches to the Short Story, Farhat Iftekharrudin, from the University of Texas, and Mary Rohrberger, from the University of New Orleans, are closely connected with the SSSS. Iftekharrudin is the editor of its journal, Short Story, and Rohrberger is co-founder of that same organization, as well as executive director of its biennial international conference. Postmodern Approaches... consists, in fact, of a selection of the papers presented at the fifth International Conference of the Short Story held in New Orleans in 1998 under the general sponsorship of the SSSS.

The editors explain in the preface that, since postmodern theory has not been applied systematically to the short story, in the present volume different approaches commonly associated with this mode of contemporary thinking will be used to study the nature of international short stories. This aim is explained in the final paragraphs of the preface, the previous four pages being devoted to a brief history of the modern short story: from the founding figures of Hawthorne, Poe or Gogol, until the most recent and most famous practitioners, like Raymond Carver and Richard Ford. Although the editors define clearly the postmodern short story in the preface, when it comes to the theoretical frame that is going to be applied to the short fiction in the chapters that follow, the first impression is that it covers an ample ground, a vast territory that makes postmodern theory tantamount to any current of thought of the last forty years: deconstruction, structuralism, reader-response criticism, semiotics, etc. The editors give equal weight to "postmodern theoretical issues and themes, such as gender and sexual roles, cultural, postcolonial, linguistic, psychological, historical studies..." (xi).

Certainly the boundaries of postmodernism have never been clearly fixed, but many would react against the ease with which it is used to contain virtually any recent theoretical development. A real engagement with the main issues of postmodernism (disconnectedness, nostalgia for lost meanings, playful superficiality, lack of artistic coherence, critical revisiting of the canon, etc.) is found missing in most of the chapters that constitute the book. Not many key authors of postmodernism appear in the work-cited lists of the different papers, either. Lacan, Barthes and Todorov are mentioned once, but there is no evidence that Lyotard, Foucault, Jameson, Kristeva, Baudrillard or Derrida have been used as a basis for the articles (nor even introductory texts by authors like Ihab Hassan, Linda 
Hutcheon or Patricia Waugh). That is not to say that the articles in the book have no academic merit; it is simply that postmodernism was perhaps not really necessary in the title. The three sections that divide the book (Part I: Discovering the Shapes of the Short Story; Part II: Exploring the World of the Short Story; Part III: Encountering Issues of Gender and Sexuality) clearly indicate that this is a standard collection of recent articles on the short story, following the trend of Lohafer and Clarey's book, and therefore not very dissimilar from other recent compilations like The Tales We Tell. Perspectives on the Short Story (1998). This latter volume was published, like Postmodern Approaches... under the auspices of the SSSS, and Mary Rohrberger appears as one of the editors as well. In The Tales We Tell the editors included contributions by established authors like John Barth or Joyce Carol Oates, but apart from that difference, the structure of the book is very similar to Postmodern Approaches...: each has sections on the form of the short story, on history and place, on roles and genres, etc. Postmodern Approaches..., in short, should be considered as an interesting book with different perspectives on the short story, and as a volume which contains some valuable pieces of criticism, but not as a significant enlargement of the theoretical problems of postmodernism in relation to the short story.

The five articles that deal with aspects of the form of the short story in the first section of the book are highly specialized, and they are aimed at scholars working on the authors whose stories are under scrutiny; there are no introductions to the authors' work, and a general knowledge on their literary production is assumed. Three of these articles are particularly relevant and, against the common trend in the book, they can claim some connection with postmodern theoretical problems. David Sheridan in "The End of the World: Closure in the Fantasies of Borges, Calvino and Millhauser" studies the endings in the stories of a group of very original authors. Frank Kermode's The Sense of an Ending is appropriately quoted in the article. In order to analyze their stories properly, Sheridan coins a useful term, AWF or Alternate World Fictions. By this expression not only does he mean those narratives which create new worlds, but fictions which also do not follow conventional rules in terms of linearity of plot. These fictions privilege elaboration: "They are worth displaying for their own sake" (2003: 11), and frequently turn to catalogues or lists which emphasize their unconventional nature. Sheridan poses the problem of how this kind of story achieves closure without the assistance of any kind of outcome of the action, and he is particularly precise at analysing the authors' strategies for ending their short fictions.

Suzanne Ferguson is also one of the contributors to Postmodern Approaches..., and her paper "Genre and the Work of Reading in Mansfield's 'Prelude' and 'At the 
Bay" is included in this section. Ferguson has a long-standing interest in short story theory, and has contributed to such important collections as the books by Lohafer and Clarey and the one by Charles E. May mentioned at the beginning of this review. On this occasion she approaches the work of Katherine Mansfield and considers the nature of the stories in two of her books. There have been numerous critical attempts to read the stories in these collections as a sequence, as befits a modernist text. However, for the author of the paper, the stories by Mansfield resist being considered together, and furthermore, they ostensibly project discontinuity and disorder. From the point of view of reader's response criticism, Ferguson studies the kind of negotiation with the text that, for some authors, has to be done in order to get an illusion of wholeness. Her proposal, however, goes in the opposite direction, as she is in favour of accepting its disconnectedness.

The other article which stands out in this section is Andrea O'Reilly Herrera's "Sandra Benítez and the Nomadic Text". The piece by O'Reilly may be of interest not only for readers and scholars of Benitez but for students of the short story as well, as it presents the coinage of another term: epi-story (episode + story), namely, a chapter in a novel which can be studied separately and works independently in the context of the book. The particular nuances that O'Reilly finds in the epi-stories of Benitez's A Place Where the Sea Remembers (1993) is a testimony to the skilfulness of contemporary theorists on the short story. Once the basics of the genre have been explored with important attempts towards definition of the short story done during the late 1980s and 1990s, scholars are now paying attention to the rarities, the hybrids, the forms on the margins of short fiction. The other two articles of the section are "The Challenge of 'June Recital': Generic Considerations in the Structure of The Golden Apples" by Donna Jarrell, and "Death and the Reader: James's 'The Beast in the Jungle"” by Arthur A. Brown.

The four papers of the second part of the book ("Exploring the World of the Short Story") constitute in fact a postcolonial section. There is an article on Australian writer Janette Turner Hospital, written by Donna J. Davis: "Postmodern Issues in Janette Turner Hospital's Nature-Dominated Short Stories 'The End-of-theline End-of-the-world Disco' and 'Our Own Little Kakadu'”; a piece on Iranian short fiction, "The Virtuous Complaint: Iranian Short Fiction of the 1960s-1970s" written by Rivanne Sandler; and Donald Petesch is the author of "Jean Toomer's Cane". In the last article of the section, "Homi K. Bhabha and the Postcolonial Short Story", Catherine Ramsdell approaches the critic who has most influenced this field of studies in the last decade. Ramsdell puts Bhabha's theories into practice with a discussion of a story by New Zealand writer Bill Manhire, in particular Bhabha's idea of moving beyond and his stand against the fixity of binary oppositions. 
The third section of the book contains three chapters which deal with issues of gender and sexuality in the short story. In the first article, "Wharton's Short Fiction of War: The Politics of 'Coming Home'”, Mary Carney demands a place for women's voices in the male-dominated literature of World War I, choosing Edith Wharton's war writings as the clearest exponents of a neglected list of texts written by women on that topic, including works by Virginia Woolf, Katherine Mansfield and Willa Cather. In the second piece, "Living in a World of Make-Believe: Fantasy, Female Identity, and Modern Short Stories by Women in the British Tradition", Adrienne Gavin studies the clashes between fantasy lives and the real world in the stories of a group of contemporary British women writers. The author provides interesting insights on the connection between female fantasy and the short story: "Fantasy in short stories by women reveals the 'unsaid and unseen' of female experience" (2003: 123). In the third and last article of the collection, "The Fourierist Parables of Guy Davenport", Patrick Meanor shows how Davenport's most successful stories simply carry out the utopian vision of Charles Fourier of an idyllic world where people get carried away by their sexual and emotional instincts.

These last three articles are representative of the collection in that they are wellwritten, and make their point efficiently, without reaching arresting conclusions. The fact that they deal with issues of gender does not place them in a more privileged position in relation to postmodernism than articles working within any other recent theoretical framework; they could have easily appeared in any contemporary compilation on the short story. Rather than making the articles of the collection fit into an all-inclusive concept, postmodernism, this volume might perhaps have framed them within an international and multicultural context. After all, the move towards diversity in short-story studies was what Mary Rohrberger (RochetteCrawley 1997: 212) defined in a recent interview as "a logical consequence".

\section{REFERENCES}

Allen, W. 1981. The Short Story in English. Oxford: Clarendon Press.

Bayley, J. 1988. The Short Story. Henry James to Elizabeth Bowen. Brighton: The Harvester Press.

Lohafer, S., and J. E. Clarey, eds. 1989. Short Story Theory at a Crossroads. Baton Rouge and London: Louisiana State University Press.

Lounsberry, B., S. Lohafer, M. Rohrberger, S. Pett and R. C. Feddersen, eds. 1998. The Tales We Tell. Perspectives on the Short Story. Westport, Connecticut, and London: Greenwood Press.

May, C. E., ed. 1994. The New Short Story Theories. Athens: Ohio University Press. 
Rochette-Crawley, S. 1997. "An Interview with Mary Rohrberger". Speaking of the Short Story. Interviews with Contemporary Writers. Eds. F. Iftekharuddin, M. Rohrberger and M. Lee. Jackson: University Press of Mississippi. 211-218. 